\title{
Routine immunization services in Pakistan: seeing beyond the numbers
}

\author{
S. Husain ${ }^{7}$ and S.B. Omer ${ }^{2}$
}

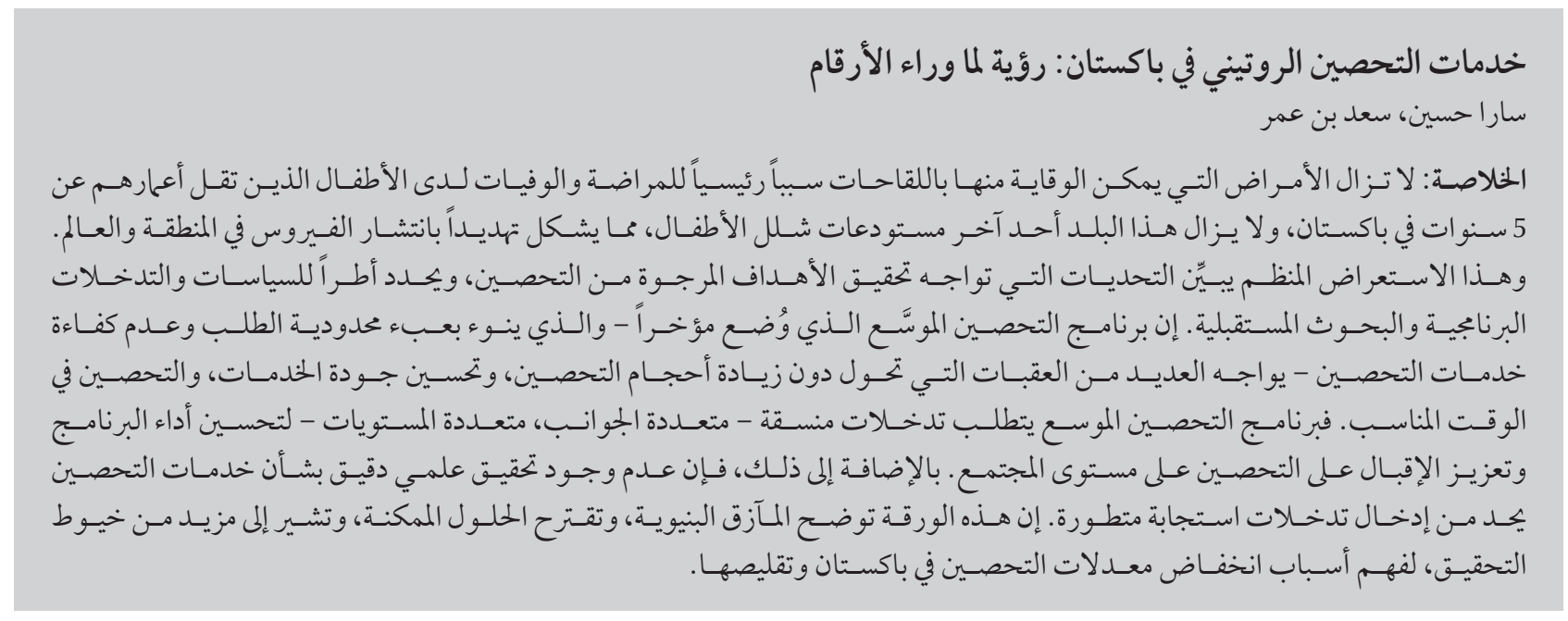

ABSTRACT Vaccine-preventable diseases continue to be a major cause of morbidity and mortality among children under 5 years of age in Pakistan, and the country remains one of the last reservoirs of polio, posing a threat of viral spread within the region and globally. This structured review describes challenges in the achievement of vaccination targets and identifies arenas for policy and programmatic interventions and future research. Burdened with limited demand and inefficient vaccination services, the recently devolved Expanded Programme on Immunization (EPI) faces multiple hurdles in increasing immunization volumes, improving the quality of services and ensuring timely vaccination. The EPI requires multi-pronged, multi-level, coordinated interventions to improve programme functioning and to enhance vaccination uptake at community level. Additionally, a lack of rigorous scientific enquiry on vaccination services limits the introduction of well-developed, responsive interventions. The paper describes systemic bottlenecks, proposes potential solutions and suggests lines of further enquiry to understand and reduce the languishing immunization rates in Pakistan.

\section{Les services de vaccination systématique au Pakistan : voir au-delà des chiffres}

RÉSUMÉ Les maladies à prévention vaccinale demeurent l'une des causes principales de morbidité et de mortalité parmi les enfants de moins de 5 ans au Pakistan, et le pays constitue l'un des derniers réservoirs de poliomyélite, représentant ainsi une menace de propagation des virus à l'échelle régionale et mondiale. Cet examen structuré décrit les défis inhérents à la réalisation des objectifs de la couverture vaccinale, et identifie les domaines qui requièrent des interventions politiques et programmatiques ainsi que de plus amples travaux de recherche. Du fait d'une faible demande et de l'inefficacité des services de vaccination, le Programme élargi de vaccination (PEV), récemment décentralisé, est confronté à de multiples obstacles dans sa démarche d'augmentation des vaccinations, d'amélioration de la qualité des services et d'administration de vaccins en temps voulu. Le PEV requiert des interventions coordonnées sur plusieurs fronts et à tous les niveaux pour améliorer son fonctionnement et augmenter l'acceptation des vaccins au niveau communautaire. De plus, un manque d'investigations scientifiques rigoureuses sur les services de vaccination empêche la mise en place d'interventions bien conçues et adaptées. La présente étude recense les obstacles systémiques, propose des solutions potentielles et suggère des axes de recherche à approfondir afin de comprendre les éléments qui entraînent la stagnation des taux de vaccination au Pakistan et d'inverser la tendance.

'Department of Paediatrics and Child Health, Karachi Aga Khan University, Karachi, Pakistan (Correspondence to S. Husain: sara.husain@aku. edu). ${ }^{2}$ Rollins School of Public Health, Emory University, Atlanta, Georgia, United States of America.

Received: 03/12/15; accepted: 21/12/15 


\section{Introduction}

A low-middle income country ofSouth Asia, Pakistan is one of the few countries in the world with persistent circulation of poliovirus, posing a threat to global polio eradication initiatives (1). Home to one of the largest birth cohorts in the developing world (2), Pakistan continues to struggle to improve routine immunization services among its under-2-year-old population of more than 10 million $(3,4)$. The sheer size of the target population presents an opportunity to intervene and achieve significant reductions in infant and child mortality at the local and regional level.

Although a significant body of work exists on childhood immunization in Pakistan, most studies have looked at individual vaccines (polio, tetanus, rotavirus, etc.) and we are not aware of a comprehensive review of the health system determinants of low immunization coverage. Significantly, no publication addresses the programmatic changes that have been made subsequent to recently enacted devolution of the public health system. With mounting international and local efforts targeting vaccination services in Pakistan, and in order to identify bottlenecks affecting programme function, we present a review paper discussing the current status of childhood vaccination in Pakistan and the renewed role of the expanded programme on immunization (EPI). We expect this paper will fill the existing knowledge gap and provide updated information to national and international programme managers, bilateral agencies and researchers interested in immunization-related investments in Pakistan.

\section{Methods}

A literature search for published articles, reports and reviews was conducted with the PubMed search engine, using the search terms "childhood immunization", "routine vaccination", "vaccines", "expanded programme on immunization" and "Pakistan". The search included all relevant articles concerning human subjects and published in English language from 1995 to 2015. A total of 410 articles were identified, of which 271 referred to immunization in Pakistan in either the title or abstract. Of these, articles pertaining to adult vaccinations (3 articles), specific vaccine-preventable ness studies (8 articles), molecular vaccine development studies (24 articles), duplicate studies (30 articles) and those not available online (2 articles) were excluded. The final analysis included 38 articles addressing childhood routine immunization services in Pakistan, the majority of which (35 articles) were descriptive studies conducted in various settings in Pakistan. Only 3 articles reported the results of randomized controlled trials conducted in peri-urban and rural settings.

Grey literature on the subject was identified by reviewing the references in the identified scientific literature and by contacting academic and public health institutes involved in EPI and systems research in Pakistan. The work identified included assessments done by the United Nations Children's Fund and the GAVI Alliance, serial Pakistan Demographic and Health Surveys, the Pakistan Social and Living Standards Measurement Survey, and provincial and national country multi-year plans for the EPI. The literature synthesized below begins with a description of the current system and state of illnesses (162 articles), vaccine effective-

immunization in Pakistan followed by an analysis of health system bottlenecks that affect routine immunization services.

\section{Results}

\section{Structure of vaccination services in Pakistan}

Established as a vertical programme in 1978, the EPI in Pakistan began with smallpox eradication and was rapidly followed by the introduction of 5 antigens within the national immunization schedule (5,6; deputy manager EPI programme, Sindh province, unpublished presentation, 2014). Currently, the programme offers a series of 9 antigens from birth to 2 years of age (Table 1). Overwhelmingly provided by the public sector (7), vaccination services in Pakistan are delivered by several cadres of health workers (8).

Vaccinators form the primary workforce for routine immunization in pre-determined catchment areas (with reference to health facilities) and out-ofcatchment areas through facility-based and outreach services. Each vaccinator is monitored and supervised by the tehsil (sub-district) and district level supervisors along with district and provincial EPI programme managers through field and facility-based visits. Additional cadres providing vaccination services during special immunization initiatives include community-based lady health workers and facility-based staff including lady health visitors, dispensers and

\begin{tabular}{ll}
\hline Table 1 Schedule of the expanded programme on immunization in Pakistan \\
\hline Age of child & Immunizations \\
Birth & OPV 0, BCG \\
6 weeks & OPV I, Penta I, PCV I \\
10 weeks & OPV II, Penta II, PCV II \\
14 weeks & OPV III, Penta III, PCV III \\
9 months & Measles I \\
15 months & Measles II \\
\hline
\end{tabular}

$O P V=$ oral polio vaccine; $B C G=$ bacille Calmette-Guérin; $P$ enta = pentavalent vaccine (diphtheria, pertussis, tetanus, hepatitis $B$, Haemophilus influenza $B$ ); $P C V=$ pneumococcal-10 vaccine. 
medical technicians. Data on daily service provision, stock utilization and cold-chain functioning are maintained through numerous facility-based registers and are collated at the end of the month for submission to higher administrative levels for future service planning and performance assessment. Monthly meetings among vaccination staff provide the forum for service and logistics planning and performance review.

\section{Status of routine immunization in Pakistan}

One of the foremost programmes established in South Asia (9), the Pakistan EPI has shown less than optimal performance over successive years of the programme, with an estimated 54\% of children under 2 years completely immunized - a rate well below recommended levels for universal vaccination (3). There is, however, considerable variation in the reported rates of completed vaccinations in under-2-year-olds, with the Pakistan Social and Living Standards Measurement Survey estimating rates of $81 \%$ and smaller observational studies estimating rates from $45 \%$ to
77\% (10-17). Significant interprovincial and sub-regional variability in vaccine coverage exists (18-22). Punjab, the most densely populated province, currently outperforms other provinces, while coverage has declined over time in Sindh and Baluchistan provinces (Figure 1).

Antigen-specific coverage, although higher than rates of completed vaccination, shows attrition over serial doses, indicating a decline in follow-up vaccination, a pattern unchanged over several years $(3,4,23-25)$. Polio immunization, however, remains consistently high for subsequent doses (Figure 2) (20). Gains in vaccination coverage over time are concentrated in urban settings, resulting in widening urban-rural disparities in vaccination coverage over the last 2 decades (Figure 3) $(11,22$ ).

Stagnating rates of immunization result from gaps in vaccine delivery (supply) on the one hand and low uptake by the population (demand) on the other hand. Bottlenecks limiting efficient and equitable delivery of vaccination services result from a complex interplay of factors including the policy environment, programme governance and capacity, as discussed below.

\section{Policy environment}

Since 1988, Pakistan and donor agencies have invested considerable resources into polio eradication, including national and sub-national immunization days. The emphasis on polio elimination has split immunization activities into routine immunization and polio elimination initiatives, often perceived as competing activities (26; EPI programme manager, Sindh province, unpublished interview, 2014). Intense utilization of the public health machinery and a concentration of resources on polio-focused activities is widely cited for shifting the focus away from routine immunization and causing "polio fatigue" among staff, managers and the community $(19,26,27)$. There is, however, little empirical evidence that this has negatively impacted routine immunization activities (28).

Public-private partnerships for service provision have gained considerable mileage in Pakistan. With nearly all provinces practising some form of publicprivate partnership at basic health units,

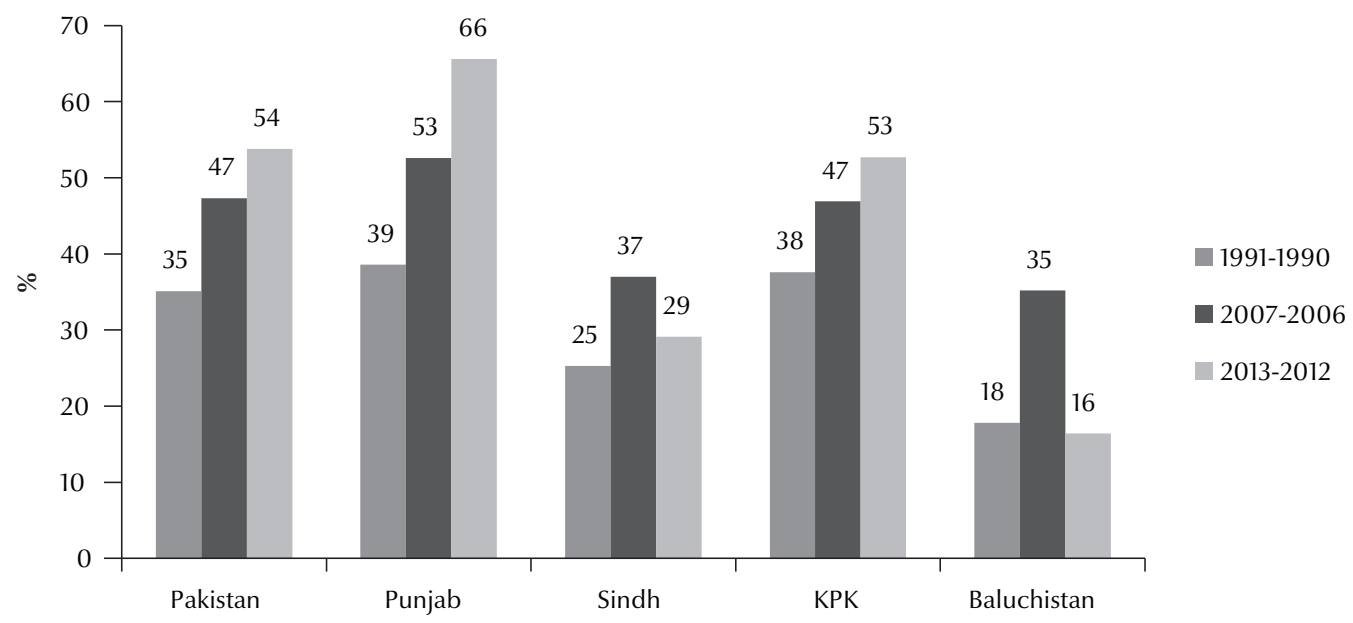

Figure 1 Vaccine coverage (all basic vaccinations) among children aged 12-23 months in Pakistan provinces. Source: Pakistan Demographic and Household Surveys 1990-1991, 2006-2007 and 2013-2014 


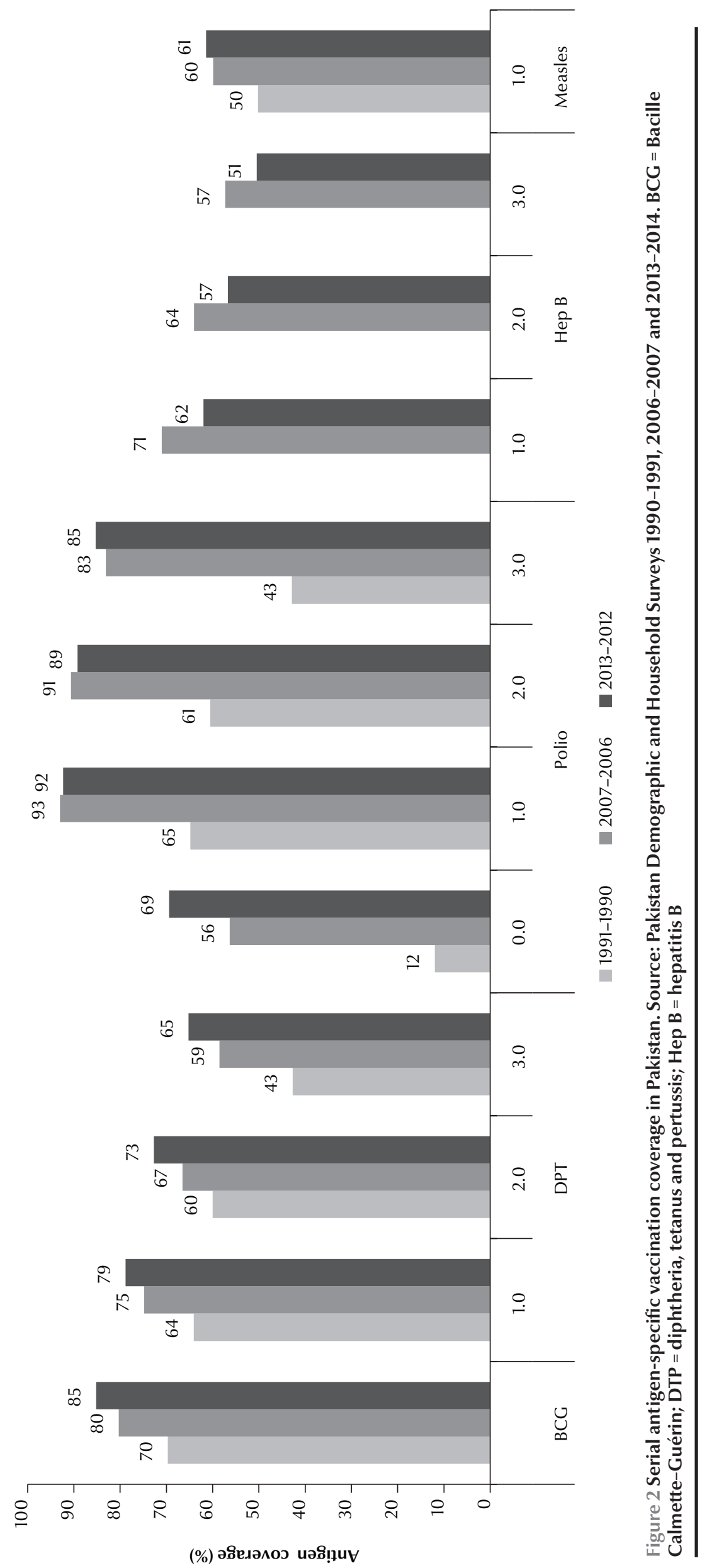

service uptake in outsourced facilities has increased (29). However, the limited scope of contractual obligations and a separation of administrative oversight of vaccinators effectively removed them from direct oversight and supervision by facility-based physicians at outsourced facilities, and vaccination coverage in these areas has remained unchanged (30).

An exclusive focus on provision of vaccination services through public sector facilities places an immense burden on already constrained resources and excludes the private sector, a major provider of health care in the Pakistani context $(9,27)$. However, involvement of this largely unregulated sector is challenging, because the partnership raises questions of service quality, effective monitoring and ensuring equity of access to vaccination services (31). As a standalone vertical programme for childhood immunization, the EPI has poor integration at different service delivery points, resulting in significant missed opportunities among women and children seeking medical services for unrelated health issues $(17,27$; EPI programme manager, Sindh province, unpublished interview, 2014).

The last census of Pakistan was conducted in 1998; projections of population demographics, vaccine requirements, procurement and distribution are based on outdated figures and there has been no systematic attempt to rationalize projected requirements by revising population estimates $(5,17)$. Outdated formulae for estimating population growth and the poor quality of vaccine coverage data seriously limit decision-making at all levels.

\section{Programme structure and management}

Pakistan's public health system has undergone considerable transformation with the local governance ordinance of 2001 followed by the 18th Amendment to the Constitution of Pakistan in 2011. These changes devolved services 


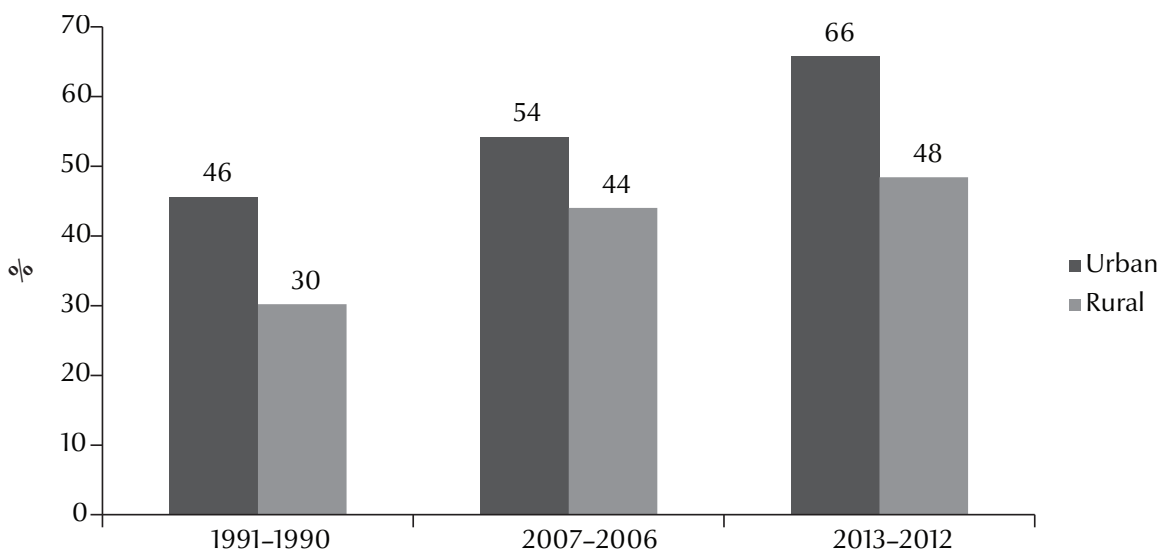

Figure 3 Urban-rural disparity in vaccination coverage among children 12-23 months of age in Pakistan. Source: Pakistan Demographic and Household Surveys 1990-1991, 2006-2007 and 2013-2014

and management of government departments to local levels, thus increasing the local role in health care provision on the strategic and operational fronts.

Local governance ordinance established the district health system, transferring responsibility of service planning, provision, monitoring and evaluation from provincial to district levels (32,33). While district coordination officers established EPI targets, human resource and bridge financing was under provincial purview, causing conflicts in programme prioritization and financing (34). Reduced federal and provincial oversight and an absence of district-based cadres for management and surveillance of EPI activities resulted in poor coordination of activities, hindered the establishment of clear roles and responsibilities within district health departments and resulted in a near stagnation of health indicators $(34,35)$. Furthermore, a lack of ringfencing of funding for the EPI at district level made financing subject to district initiative and discretion in the face of competing interests $(5,26,36,37)$.

With the 18th Amendment of the Constitution, the legislative and executive functions of health and vertical programmes were completely devolved to the provinces, including developing and implementing provincial policies, programme financing, implementation and monitoring. However, commoninterest demands for regulation, national and international coordination, interprovincial coordination and conformity resulted in the federal EPI programme being housed within the Ministry of Health in the period since the 18th Amendment, as mentioned in Table 2 (8). After June 2015, when most provincial mid-term plans will conclude, each province will be responsible for procurement and distribution of vaccines along with guidance and supervision of districts. To date, however, there has been little progress on development of EPI policies and financing lines for the programme at provincial level (30,38-40).

Donor and partner agencies play a significant role in all aspects of programme operations involving routine immunization and polio elimination initiatives, by engaging all tiers of the EPI programme, public sector machinery and not-for-profit organizations. Inputs include policy development, programme planning, vaccine and cold-chain procurement, deployment and training of human resources, demand generation through civil society organization, enhanced monitoring and improved reporting of services through computerized vaccine logistics management information systems and smart-phone monitoring of vaccinators. In the one-window operation for donor coordination at the federal EPI cell, it is essential that the provinces provide a significant contribution to account for inter-provincial variability and enable improved coordination and consensus building at the national level.

\section{Programme governance and capacity}

Before the 18th Amendment, provincial EPI offices acted on policies and targets established by the federal EPI office, distributed vaccine stocks and supplies to districts, collated district level data, monitored service provision and trained staff. Limited involvement in policy development, donor engagement, partner coordination and vaccine forecasting, compounded by a paucity of manpower to manage and coordinate service delivery, severely limited the provincial EPI cells from effectively taking on the mantle of control transferred by the 18th Amendment. Furthermore, a lack of provincial engagement in cooperative development of micro-plans with districts, poor defaulter tracing (identification of children who miss a scheduled vaccine dose by more than 1 month) and deficient service monitoring have resulted in weak capacity-building and 


\begin{tabular}{|c|c|}
\hline Programme component & Actions \\
\hline Programme management & $\begin{array}{l}\text { - Development and implementation of national EPI policy } \\
\text { - Interprovincial coordination }\end{array}$ \\
\hline Service delivery & - Development of national standards for service delivery and safe vaccination policies \\
\hline Human resource & - Establishing accreditation rules and standards \\
\hline Cost and financing & $\begin{array}{l}\text { - Co-financing commitments (until June 2015) } \\
\text { - Mobilization and coordination of donor financing }\end{array}$ \\
\hline Vaccine, cold-chain and logistics & $\begin{array}{l}\text { - Procurement of vaccines and injection supplies } \\
\text { - Procurement of cold-chain }\end{array}$ \\
\hline Surveillance and reporting & $\begin{array}{l}\text { - Consolidation of provincial reports and generation of national reports } \\
\text { - Coordination, information collection and sharing at national and international forums }\end{array}$ \\
\hline Demand generation & - Development of national communication strategies and guidelines \\
\hline
\end{tabular}

restricted collaborative learning at the provincial and district levels $(35,41)$.

A lack of succession planning, and frequent transfers within management tiers, result in loss of institutional memory and limit knowledge transfer. With no systematic, formal training programmes for management cadres, learning is mostly self-directed and onthe-job and managers often lack the relevant technical knowledge for directing efficient programme operations $(9,26)$. Unclear roles and responsibilities, poor programme governance, lack of stewardship at decision-making levels and political interference have caused rampant inefficiencies and have hindered EPI performance at nearly all operational levels (27,42,43; EPI programme manager, Sindh province, unpublished interview, 2014).

\section{Quality of vaccination services}

Pre-induction training of vaccinators includes EPI schedules, cold-chain maintenance and safe injection practices. Refresher training is conducted when a new vaccine is introduced (EPI programme manager, Sindh province, unpublished interview, 2014); there are, however, no opportunities for regular refresher training. Importantly, training on counselling skills, adverse event reporting, defaulter tracing and integrated service provision are not conducted, resulting in low levels of knowledge about vaccines and immunization services among vaccinators and allied staff (41; EPI programme manager, Sindh province, unpublished interview, 2014). Despite the existence of waste management policies in all provinces of Pakistan (30,38-40), safe disposal of used syringes is not stringently practised, highlighting a need for continued education, training and monitoring of staff on injection hazards and safe disposal of vaccine-related consumables.

Vaccinators form the core workforce for outreach immunization services. However, significant political patronage, poor human resource management and limited local ownership have resulted in workforce maldistribution and frequent absenteeism. Poor outreach performance is often attributed to lack of transport funds; in 2012 an estimated 3-5\% of programme expenditure was on transportation, including programme operations, logistics, monitoring and service provision $(18,26,27,30,38-40,43)$. Vaccinators often do not develop or update monthly micro-plans and defaulter lists for service provision in catchment areas, accounting for a loss to follow-up among local populations $(26,30,38-40,43)$.

Although static vaccination centres are housed in health facilities, close to $13 \%$ of union councils in Pakistan (the lowest level of government, comprising a village or urban area and its surroundings) do not offer immunization services at existing facilities $(5,8,30,38-40)$. Most vaccination points have visual aids, e.g. posters and banners providing information about vaccines to visiting parents. Owing to the limited financial outlay for communication and advocacy, however, there are no take-home EPI promotional materials $(8,17,38)$. Parents are only provided with vaccination cards which carry information on administered vaccines and immunization dates. Service providers often fail to emphasize the importance of these cards to parents, resulting in low rates of card retention and poor knowledge of the purpose of cards $(21,26,44)$. When health care providers inform parents about the due dose they often fail to counsel them on the importance of completing vaccinations as per the schedule and on dealing with vaccine side-effects.

Shortages of vaccines, consumables and recording tools, including EPI cards and registers, also hampers provision of vaccination services; in 2012 close to $17 \%$ of basic health units and $7 \%$ of rural health centres had fewer than $25 \%$ of vaccine antigens (45). Bacille Calmette-Guérin and measles vaccine vials are opened on designated days to reduce wastage, information which remains poorly communicated to the community. Vaccine shortages and designated days for special vaccinations 
send a negative message to care-seekers on the future availability of vaccination services and hence deter people from seeking these services.

Inefficiencies of cold storage include absent or non-functional coldchain equipment, persistent electrical outages and improper stocking that potentially limits antigen efficacy. The absence of a cold-chain replacement plan and a lack of routine examination of existing units and record-keeping on equipment distribution hampers timely identification and replacement of ailing units $(30,40)$. Additionally, a lack of funds and a paucity of biomedical equipment expertise at district level limits proper maintenance and repair of existing cold-chain equipment $(26,41,43,46)$.

Records of routine immunization services provided at public health facilities are maintained through 11 different paper-based tools used for recording details of daily and monthly EPI services. Often these registers are poorly maintained and there is no effort to confirm reported information from nearby catchment populations, thus causing reporting errors $(5,17,26)$. Detailed analysis of coverage reports submitted at sub-district and district level offices is not routinely conducted, with few districts reporting vaccine coverage exceeding $100 \%(17,18)$

Low vaccine demand also accounts for declining rates of completed vaccination among children. Vaccine demand is correlated with parental knowledge of vaccine importance, parental education and socioeconomic status $(43,47,48)$. Published data indicate that higher maternal education is positively associated with vaccine uptake $(4,10,14,22)$. Despite rising trends in vaccination uptake over time, the rate of vaccine uptake is slower among parents of lower education levels, thus highlighting the need to develop advocacy and communication strategies specifically designed to address caregivers with little educational attainment (Figure 4) (14,21,49-51).

It has been widely established that "belief in the goodness of vaccination" is considerably more important for motivating caregivers than scientific knowledge about vaccines $(14,22,48,52-54)$. Mothers unaware of vaccine side-effects were more likely to have their children vaccinated (22) and, paradoxically, fear of common side-effects was linked to vaccine refusal $(14,22)$, indicating the importance of proper counselling of caregivers before and after vaccinating a child.
Limited geographical access and inconvenient opening times at EPI centres limit patients' physical access to vaccination services $(21,25,26)$. Most public facilities in Pakistan function between 09.00 and 14.00 hours, thus limiting access to services to a few hours in the day. Women attending antenatal services, receiving prenatal tetanus vaccinations or delivering at a health facility were more likely to have their children vaccinated $(4,10,13,48)$, indicating that positive health-seeking behaviours are associated with improved uptake of services over time and between generations.

Cultural resistance to vaccination uptake is fuelled by fear of side-effects, prior experiences of vaccine side-effects and local myths of "vaccine-induced infertility" among children. These themes are also packaged in religious messages and are propagated by religious leaders, who are often local opinion-makers. Increasing resistance to vaccination uptake particularly for polio vaccination has been reported in pockets of the country, coupled with rising violence targeting polio campaign workers in different cities of Pakistan (55).

A summary of the barriers limiting achievement of universal vaccination in Pakistan and potential avenues for action are shown in Table 3.

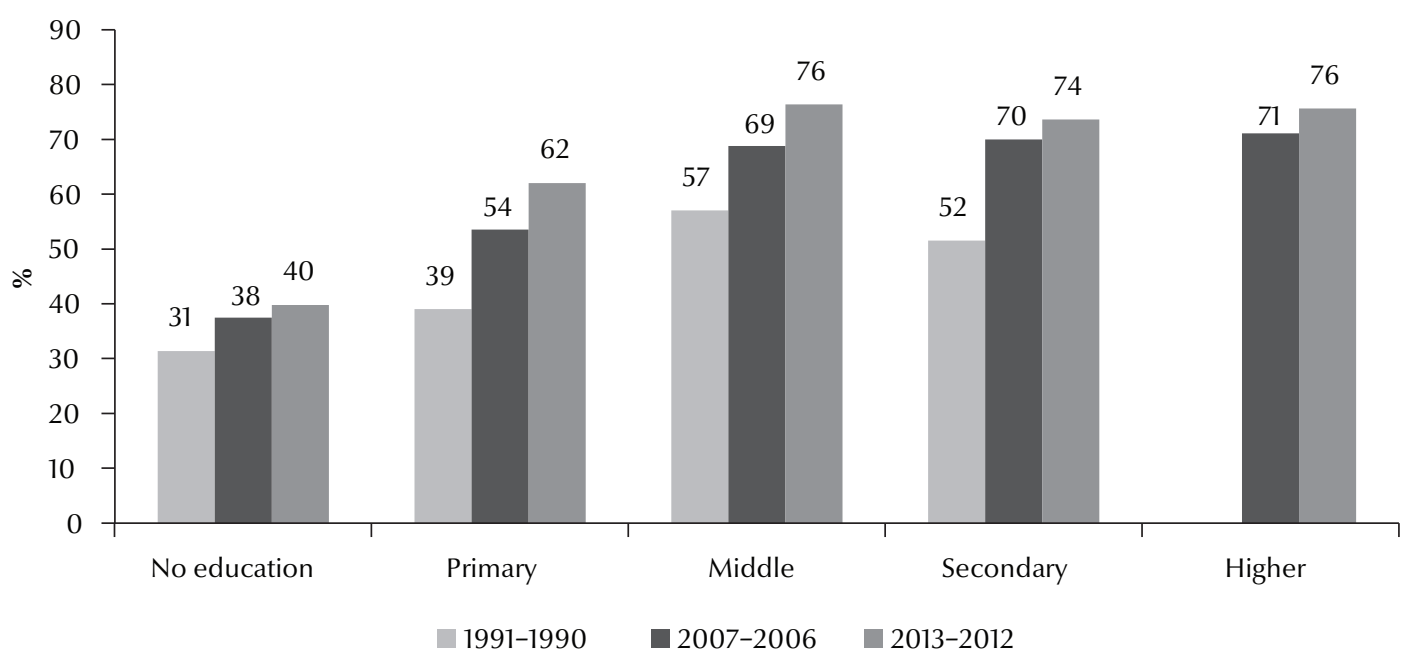

Figure 4 Effect of caregiver education level on immunization uptake in Pakistan. Source: Pakistan Demographic and Household Surveys 1990-1991, 2006-2007 and 2013-2014 


\begin{tabular}{|c|c|c|}
\hline Theme & Challenges & Recommendations \\
\hline $\begin{array}{l}\text { Programme structure } \\
\text { and management }\end{array}$ & $\begin{array}{l}\text { - Ambiguous division of roles and } \\
\text { responsibilities of EPI activities following } \\
\text { the 18th Amendment of the Constitution } \\
\text { of Pakistan } \\
\text { - Common pool of funds at district level, } \\
\text { making EPI a competitor for funds and } \\
\text { making allocations discretionary }\end{array}$ & $\begin{array}{l}\text { Development of a renewed scope of work and } \\
\text { provincial procedures for accountability and } \\
\text { monitoring structures for different tiers and actors } \\
\text { involved in EPI service provision } \\
\text { - Introduce activity-specific funding for all health } \\
\text { programmes including immunization at district } \\
\text { level to ensure adequate capitalization for target } \\
\text { achievement }\end{array}$ \\
\hline $\begin{array}{l}\text { Programme } \\
\text { governance and } \\
\text { capacity }\end{array}$ & $\begin{array}{l}\text { - Limited managerial capacity and trained } \\
\text { human resources for programme } \\
\text { implementation at district and sub- } \\
\text { district levels } \\
\text { - Poorly implemented structures of } \\
\text { accountability exacerbated by political } \\
\text { patronage and interference }\end{array}$ & $\begin{array}{l}\text { Regular, level-specific training for managerial tiers } \\
\text { institutionalized by district and provincial health } \\
\text { departments } \\
\text { - Institutional strengthening with improved } \\
\text { monitoring and accountability of concerned cadres } \\
\text { of managers and frontline workers }\end{array}$ \\
\hline Human resources & $\begin{array}{l}\text { - Lack of rational deployment of trained } \\
\text { human resources } \\
\text { - Lack of refresher training of } \\
\text { health care providers on vaccine- } \\
\text { preventable illnesses, newer vaccines, } \\
\text { communication skills and adverse events } \\
\text { reporting } \\
\text { - Poor coordination among different } \\
\text { cadres of field-based staff }\end{array}$ & $\begin{array}{l}\text { - GIS mapping of human resources and catchment } \\
\text { populations for rational redeployment } \\
\text { - Employee development initiatives with official } \\
\text { avenues for regular training and skill development } \\
\text { - Implementation of collaborative planning, } \\
\text { micro-plan development and service provision } \\
\text { at community level among frontline workers. } \\
\text { Members of community may be involved to } \\
\text { enhance development of collaborative and needs- } \\
\text { responsive micro-plans }\end{array}$ \\
\hline Vaccine logistics & $\begin{array}{l}\text { - Centrally driven demand estimation } \\
\text { based on historical trends of inconsistent } \\
\text { data } \\
\text { - Poorly sustained cold-chain } \\
\text { maintenance }\end{array}$ & $\begin{array}{l}\text { - Rationalize demand estimation based on locally } \\
\text { available facility- and community-based databases } \\
\text { - Regular mapping of cold-chain assets with } \\
\text { identification of non-functional units for repair/ } \\
\text { replacement } \\
\text { - Development of local (district/sub-district) funds } \\
\text { for cold-chain repair and replacement }\end{array}$ \\
\hline $\begin{array}{l}\text { EPI management } \\
\text { information system }\end{array}$ & $\begin{array}{l}\text { - Poor record-keeping in EPI management } \\
\text { information system and limited } \\
\text { utilization of submitted data for } \\
\text { decision-making } \\
\text { - Absence of feedback at district level for } \\
\text { improving data quality }\end{array}$ & $\begin{array}{l}\text { - Establishment of district data-cells to conduct } \\
\text { regular sub-district surveys to obtain accurate } \\
\text { estimates of vaccine coverage } \\
\text { - Rationalization and revision of paper based } \\
\text { management information tools } \\
\text { - Adoption of mobile device-based technology for } \\
\text { rapid service data collection } \\
\text { - Rigorous and regular assessment of submitted } \\
\text { service data, with timely feedback to improve and } \\
\text { maintain data quality }\end{array}$ \\
\hline $\begin{array}{l}\text { Poor community } \\
\text { uptake of vaccinations }\end{array}$ & $\begin{array}{l}\text { - No appreciable increase in vaccine } \\
\text { uptake among illiterate and low-income } \\
\text { segments of society } \\
\text { - Poor communication skills of health } \\
\text { care providers and high rate of missed } \\
\text { opportunities } \\
\text { - Cultural and religious myths propagated } \\
\text { by influential community leaders to } \\
\text { prevent uptake of vaccination }\end{array}$ & $\begin{array}{l}\text { - Development of evidence-based communication } \\
\text { packages focusing on service uptake among } \\
\text { different segments of society, e.g. rural populations } \\
\text { and people with low literacy } \\
\text { - Regular training of health care providers to enhance } \\
\text { technical knowledge, communication skills and } \\
\text { staff attitudes regarding vaccination services } \\
\text { - Provision of effective communication materials for } \\
\text { use by health care providers and for distribution } \\
\text { among parents } \\
\text { - Engagement of community and religious leaders } \\
\text { to lend public support to religious instruction } \\
\text { activities in the local context } \\
\text { - Introduction of EPI services in health facilities } \\
\text { where they are currently not offered } \\
\text { - Visible, well-lit signboards identifying EPI centres } \\
\text { at health care facilities and conveying information } \\
\text { about the centre and services provided }\end{array}$ \\
\hline
\end{tabular}

$E P I=$ expanded programme on immunization; $G I S=$ geographic information system. 


\section{Discussion and policy recommendations}

With close to 4 in 10 children in Pakistan not fully immunized in their first year of life (43), urgent attention needs to be paid to service delivery and demand for vaccination among the general public. Although devolution of health services has afforded considerable policy and resource space for improved performance of the local health care systems, entrenched systemic bottlenecks need to be identified, scientifically evaluated and addressed to achieve sustainable improvements in programme performance. While generic recommendations can be made, these need to be contextualized given variable interprovincial and inter-district performance (22). Besides initiating immediate steps to improve vaccination services, it is essential to identify and rectify strategic factors affecting uptake of vaccination services, including health-seeking behaviour, community-based perceptions regarding vaccines and women's education and autonomy $(49,53,56)$. The specific recommendations are summarized in Table 3. Briefly, in the post18th-Amendment scenario, provincial EPI programmes in collaboration with departments of health, district governments and implementation partners should develop a renewed scope of work for each tier of programme functioning, with procedures for accountability and monitoring of EPI activities $(57,58)$. Provincial and national comprehensive multi-year plans have been developed after much deliberation and consensus building. These plans need to be vigorously followed up and implemented to improve EPI performance through collaborative action.

Level-specific training should be developed and institutionalized to improve managerial skills among EPI management tiers and service providers, and poor structures of governance must be addressed through institutional strengthening and improved monitoring and accountability of concerned cadres of managers and frontline workers.

Coverage of vaccination services can be improved through rational redeployment of vaccinators and task-shifting involving training and deployment of additional community-based service providers, e.g. lady health workers and community midwives for immunizing children within their catchment areas, leaving vaccinators to focus on areas not covered by allied workers.

Outdated and inaccurate systems of data collection and collation need review to improve the rigour and validity of collected data. Adaptation of modern technology, including mobile-device supported health initiatives to reduce workload must be considered for rapid data collection, making data-based decision-making faster and easier and allowing efficient management of scarce resources (59). Bottlenecks in vaccine delivery and storage must be identified, and sustainable solutions developed, for ensuring uninterrupted vaccine supplies at local levels.

Demand creation through regular reminders, mass communication programmes and grassroots level engagement are essential to combat community misperceptions and to increase acceptance of vaccination services (60). Despite engagement of the not-forprofit sector in advocacy and promotion at grassroots levels, their impact on vaccination uptake is yet to be studied (61). Consequently, these well-placed institutions remain undirected by relevant research, thus failing to capitalize on the significant potential for change. It is imperative that work conducted by these organizations be mapped and systematically evaluated to assess their relevance and enhance their contribution to the pool of immunization-focused activities within Pakistan (62).

It is through immediate, comprehensive and data-driven planning and sustained action that the languishing rates of routine immunization in Pakistan can be improved, leading in turn to reductions in local and regional mortality rates and the achievement of longterm improvements in the health of the country's children.

Funding: None.

Competing interests: None declared.

\section{References}

1. Polio vaccines: WHO position paper, January 2014. Wkly Epidemiol Rec. 2014 Feb 28;89(9):73-92. PMID:24707513

2. State of the world's children. New York (NY): United Nations Children's Fund; 2009.

3. Pakistan Demographic and Health Survey 2012-2013. Calverton (MD): National Institute of Population Studies (Pakistan) and ICF International (https://dhsprogram.com/pubs/pdf/ FR290/FR290.pdf, accessed 9 February 2016).

4. Zaidi SM, Khowaja S, Kumar Dharma V, Khan AJ, Chandir S. Coverage, timeliness, and determinants of immunization completion in Pakistan: evidence from the Demographic and Health Survey (2006-07). Hum Vaccin Immunother. 2014;10(6):171220. PMID:24784118
5. Masud T, Navaratne KV. The expanded program on immunization: recommendations for improving performance in health, nutrition and policy. Discussion Paper. Washington DC: International Bank for Reconstruction and Development; 2011.

6. Immunization in Pakistan. Islamabad, Pakistan: Pakistan Institute of Legislative Development and Transparency; 2010.

7. Expanded programme on immunization coverage evaluation survey, 2006-2007. Islamabad: Pakistan Ministry of Health; 2007.

8. Comprehensive multiyear plan 2014-2018. Expanded programme on immunization. Islamabad, Pakistan: Pakistan Ministry of National Health Services, Regulation and Coordination; 2013. 
9. Hasan Q, Bosan AH, Bile KM. A review of EPI progress in Pakistan towards achieving coverage targets: present situation and the way forward. East Mediterr Health J. 2010;16 Suppl:S31-8. PMID: 21495586

10. Ahmad R, Alvi SS, Hassan M, Kamin M, Malik M, Sarwar L, et al. Availability of expanded programme of immunization services provided to children in a rural Pakistani village. J Pak Med Assoc. 2011 Apr;61(4):415-8. PMID:21465992

11. Naeem M, Khan MZUI, Adil M, Abbas SH, Khan MU, Khan A, et al. Inequity in childhood immunization between urban and rural areas of Peshawar. J Ayub Med Coll Abbottabad. 2011 JulSep;23(3):134-7. PMID:23272455

12. Sheikh A, Iqbal B, Ehtamam A, Rahim M, Shaikh HA, Usmani $\mathrm{HA}$, et al. Reasons for non-vaccination in pediatric patients visiting tertiary care centers in a polio-prone country. Arch Public Health. 2013;71(1):19. PMID:23848348

13. Siddiqi N, Khan A, Nisar N, Siddiqi AE. Assessment of EP (expanded program of immunization) vaccine coverage in a peri-urban area. J Pak Med Assoc. 2007 Aug;57(8):391-5 PMID:17902521

14. Siddiqui NT, Owais A, Agha A, Karim MS, Zaidi AK. Ethnic disparities in routine immunization coverage: a reason for persistent poliovirus circulation in Karachi, Pakistan? Asia Pac J Public Health. 2014 Jan;26(1):67-76. PMID:23420055

15. Tarin E, Khalil M, Alvi ZM, Mustafa T, Sy FS, Thompson SJ, et al. Impact of community-based intervention on immunization coverage against vaccine-preventable diseases in Pakistan. Pak J Health. 1999;36(1):53-6.

16. Pakistan social and living standards measurement survey 2012 2013. Islamabad, Pakistan: Pakistan Bureau of Statistics; 2013.

17. Owais A, Khowaja AR, Ali SA, Zaidi AK. Pakistan's expanded programme on immunization: an overview in the context of polio eradication and strategies for improving coverage. Vaccine. 2013 Jul 18;31(33):3313-9. PMID:23707167

18. Consultants Consortium SoSec KEMC. 2000 PAK: Third party evaluation of expanded programme on immunization, Punjab [Internet]. Geneva: United Nationals Children's Fund; 2000 (http://www.unicef.org/evaldatabase/index_14212.html, accessed 9 February 2016).

19. Hong R, Banta JE. Effects of extra immunization efforts on routine immunization at district level in Pakistan. East Mediterr Health J. 2005 Jul;11(4):745-52. PMID:16700391

20. Khan A, Khan A. Childhood immunization in Pakistan. Research and Development Solutions Policy Briefs Series No. 3. Washington (DC): United States Agency for International Development; 2013 (http://resdev.org/files/policy_brief/3/3. pdf, accessed 9 February 2016).

21. Khowaja AR, Zaman U, Feroze A, Rizvi A, Zaidi AKM, Routine EPI coverage: sub-district inequalities and reasons for immunization failure in a rural setting in Pakistan. Asia Pac J Public Health. 2015 Mar;27(2):NP1050-9. PMID:22186395

22. Cockcroft A, Andersson N, Omer K, Ansari NM, Khan A Chaudhry UU, et al. One size does not fit all: local determinants of measles vaccination in four districts of Pakistan. BMC Int Health Hum Rights. 2009 Oct 14;9 Suppl 1:S4. PMID:19828062

23. Pakistan Demographic and Health Survey, 1990/1991. Columbia (MD): IRD/Macro International Inc. and Pakistan National Institute of Population Studies; 1992 (http://dhsprogram. com/pubs/pdf/FR29/FR29.pdf, accessed 9 February 2016).

24. Pakistan Demographic and Health Survey 2006-07. Calverton (MD): Macro International Inc. and Pakistan National Institute of Population Studies; 2008 (https://dhsprogram.com/pubs/ pdf/FR200/FR200.pdf, accessed 9 February 2016).

25. Usman HR, Kristensen $\mathrm{S}$, Rahbar $\mathrm{MH}$, Vermund $\mathrm{SH}$, Habib F, Chamot E. Determinants of third dose of diphtheria-tetanus- pertussis (DTP) completion among children who received DTP1 at rural immunization centres in Pakistan: a cohort study. Trop Med Int Health. 2010 Jan;15(1):140-7. PMID:19930140

26. Faisal A. Understanding barriers to immunization in Pakistan. Islamabad, Pakistan: Ministry of Health, Expanded Programme on Immunization; 2009.

27. Mangrio NK, Alam MM, Shaikh BT. Is expanded programme on immunization doing enough? Viewpoint of health workers and managers in Sindh, Pakistan. J Pak Med Assoc. 2008 Feb;58(2):64-7. PMID:18333522

28. Closser S, Cox K, Parris TM, Landis RM, Justice J, Gopinath R, et al. The impact of polio eradication on routine immunization and primary health care: a mixed-methods study. J Infect Dis. 2014 Nov 1;210 Suppl 1:S504-13. PMID:24690667

29. Quarterly performance review, April-June 2013, Karachi, Pakistan: People's Primary Healthcare Initiative; 2013.

30. Comprehensive multi-year plan 2014-2018: immunization program of Punjab province. Islamabad, Pakistan: Expanded Programme on Immunization, 2014.

31. Osman FA. Public-private partnership in health service delivery: lessons from Bangladesh. Dhaka: Department of Public administration, University of Dhaka; 2008 (http://crossasiarepository.ub.uni-heidelberg.de/144/1/Osman_Partnership_ in_health_service_delivery.pdf, accessed 9 February 2016).

32. Ansari U, Cockcroft A, Omer K, Ansari NM, Khan A, Chaudhry $U U$, et al. Devolution and public perceptions and experience of health services in Pakistan: linked cross sectional surveys in 2002 and 2004. BMC Health Serv Res. 2011;11 Suppl 2:S4. PMID:22375682

33. Local government plan 2000. Islamabad, Pakistan: National Reconstruction Bureau, Government of Pakistan; 2000.

34. Health systems governance challenges and opportunities after devolution. Research and Development Solutions Policy Briefs Series No. 29. Washington (DC): United States Agency for International Development; 2012 (http://www.resdev.org/files/ policy_brief/29/29.pdf, accessed 9 February 2016).

35. Comprehensive multi-year national Immunization strategic plan 2011-2015. Islamabad, Pakistan: Government of Pakistan; 2010.

36. Hasnain Z. Devolution, accountability, and service delivery in Pakistan. Pak Dev Rev. 2010;49(2):129-52.

37. Shaikh S, Naeem I, Nafees A, Zahidie A, Fatmi Z, Kazi A. Experience of devolution in district health system of Pakistan: perspectives regarding needed reforms. J Pak Med Assoc. 2012 Jan;62(1):28-32. PMID:22352097

38. Comprehensive multiyear plan. Immunization program of Sindh province. Islamabad, Pakistan: Expanded Programme on Immunization; 2014 (http://epi.gov.pk/wp-content/uploads/2014/09/SIN.pdf, accessed 9 February 2016).

39. Comprehensive multiyear plan: immunization program of Baluchistan province. Islamabad, Pakistan: Expanded Programme on Immunization; 2014 (http://epi.gov.pk/wp-content/uploads/2014/09/BAL.pdf, accessed 9 February 2016).

40. Comprehensive multiyear plan: immunization program of FATA. Islamabad, Pakistan: Expanded Programme on Immunization, 2014.

41. Mushtaq MU, Shahid U, Majrooh MA, Shad MA, Siddiqui AM, Akram J. From their own perspective-constraints in the polio eradication initiative: perceptions of health workers and managers in a district of Pakistan's Punjab province. BMC Int Health Hum Rights. 2010;10(22):22. PMID:20731832

42. Shaikh BT, Hafeez A. Strengthening health system with key strategies in the post devolution times in Pakistan. Position Paper Series No. 2. Islamabad, Pakistan: Health Services Academy; 2012 (http://hsa.edu.pk/aboutus/hsa-pub/position-papers/ 
HSA\%20Position\%20paper\%20No\%202-Strengthening\%20 health\%20system\%20\%281\%29.pdf, accessed 9 February 2016).

43. Shah F, Bashir-ul-Haq M, Navaratne KV, Inaam-ul-Haq TM Kostermans K, Presthus G, et al. Situation analysis: new vaccine introduction in an under-performing programme-a dilemma for Pakistan. J Pak Med Assoc. 2013;63(8):997-1002.

44. Sheikh SS, Ali SA. Predictors of vaccination card retention in children 12-59 months old in Karachi, Pakistan. Oman Med J. 2014 May;29(3):190-3. PMID:24936268

45. Health facility assessment. Sindh provincial report. Lahore: Technical Resource Facility; 2012 (http://www.trfpakistan.org/ LinkClick.aspx?fileticket=DVWqxBDJs6s\%3D\&tabid=2618, accessed 9 February 2016).

46. Cold chain inventory system in selected districts of Pakistan (preliminary analysis report). Islamabad, Pakistan: United Nations Children's Fund; 2014.

47. Coverage evaluation survey expanded program on immunization. Islamabad, Pakistan: Ministry of Health: 2006

48. Bugvi AS, Rahat R, Zakar R, Zakar MZ, Fischer F, Nasrullah $M$, et al. Factors associated with non-utilization of child immunization in Pakistan: evidence from the Demographic and Health Survey 2006-07. BMC Public Health. 2014;14(232):232. PMID:24602264

49. Owais A, Hanif B, Siddiqui AR, Agha A, Zaidi AK. Does improving maternal knowledge of vaccines impact infant immunization rates? A community-based randomized-controlled trial in Karachi, Pakistan. BMC Public Health. 2011;11(239):239. PMID:21496343

50. Usman HR, AkhtarS, Habib F, Jehan I. Redesigned immunization card and center-based education to reduce childhood immunization dropouts in urban Pakistan: a randomized controlled trial. Vaccine. 2009 Jan 14;27(3):467-72. PMID:18996423

51. Zaidi SM, Khowaja S, Kumar Dharma V, Khan AJ, Chandir S. Coverage, timeliness, and determinants of immunization completion in Pakistan: evidence from the Demographic and Health Survey (2006-07). Hum Vaccin Immunother. 2014;10(6):1220.PMID:24784118
52. Favin M, Steinglass R, Fields R, Banerjee K, Sawhney M. Why children are not vaccinated: a review of the grey literature. Int Health. 2012 Dec;4(4):229-38. PMID:24029668

53. Lambo JA, Nagulesapillai T. Neonatal tetanus elimination in Pakistan: progress and challenges. Int J Infect Dis. 2012 Dec;16(12):e833-42. PMID:22940280

54. Andersson N, Cockcroft A, Ansari NM, Omer K, Baloch M, Ho Foster A, et al. Evidence-based discussion increases childhood vaccination uptake: a randomised cluster controlled trial of knowledge translation in Pakistan. BMC Int Health Hum Rights. 2009;9 Suppl 1:S8. PMID:19828066

55. Warraich HJ. Religious opposition to polio vaccination. Emerg Infect Dis. 2009 Jun;15(6):978. PMID:19523311

56. Wado YD, Afework MF, Hindin MJ. Childhood vaccination in rural southwestern Ethiopia: the nexus with demographic factors and women's autonomy. Pan Afr Med J. 2014 Jan 18;17 Suppl 1:9.PMID:24624243

57. Schwartz JB, Bhushan I. Improving immunization equity through a public-private partnership in Cambodia. Bull World Health Organ. 2004 Sep;82(9):661-7. PMID:15628203

58. Levin A, Kaddar M. Role of the private sector in the provision of immunization services in low- and middle-income countries. Health Policy Plan. 2011 Jul;26 Suppl 1:i4-12. PMID:21729916

59. Teng JE, Thomson DR, Lascher JS, Raymond M, Ivers LC. Using Mobile Health (mHealth) and geospatial mapping technology in a mass campaign for reactive oral cholera vaccination in rural Haiti. PLoS Negl Trop Dis. 2014;8(7):e3050. PMID:25078790

60. Oyo-Ita A, Nwachukwu CE, Oringanje C, Meremikwu MM. Interventions for improving coverage of child immunization in low- and middle-income countries. Cochrane Database Syst Rev. 2011; (7):CD008145. PMID:21735423

61. Zaidi A, Khan A. Evaluation of GAVI support to civil society organisations. Country evaluation report: Pakistan. Islamabad, Pakistan: GAVI Alliance: 2012.

62. Suryadevara M, Bonville CA, Ferraioli F, Domachowske JB. Community-centered education improves vaccination rates in children from low-income households. Pediatrics. 2013 Aug;132(2):319-25. PMID:23837177 